\title{
Does SCA45 Cause Very Late-Onset Pure Cerebellar Ataxia?
}

Thiago Y. Tonholo Silva, MD, Augusto B.R. Rosa, MD, Caio R. Quaio, MD, Dineke Verbeek, PhD, José Luiz Pedroso, MD, PhD, and Orlando Barsottini, MD, PhD

Neurol Genet 2021;7:e581. doi:10.1212/NXG.0000000000000581

Spinocerebellar ataxias (SCAs) are a large group of genetically and phenotypically heterogeneous autosomal dominant, neurodegenerative disorders manifesting with progressive cerebellar ataxia usually with adult-onset. ${ }^{1}$ Currently, 48 subtypes of SCAs are described; of which, for 40 SCAs, the genes have been identified. The most frequent types are related to coding repeat expansions including SCA1, SCA2, SCA3, SCA6, and SCA7. However, for unusual SCA types, whole exome sequencing (WES) is necessary to identify the genetic cause. Late-onset cerebellar ataxia can be caused by several genetic mutations, but a large percentage of patients remain undiagnosed after WES.

In this article, we describe 2 siblings who presented with very late-onset cerebellar ataxia, mild cerebellar atrophy, and whose genetic investigation disclosed a novel heterozygous c.10906T $>$ G, p.Tyr3636Asp FAT2 (SCA45) missense variant. In addition, given that the variant is novel, affects a conserved amino acid, and segregates with disease in combination with the previous report on missense variants in FAT2, we may classify this variant of unknown significance as likely pathogenic.

\section{Case Reports}

\section{Patient 1}

An 86-year-old man presented with a progressive ataxia that started at 70 years of age. At 81 years, he developed dysarthria and dysphagia and started using a wheelchair at the age of 84 years. Family history was remarkable for cerebellar ataxia (figure A). Neurologic examination showed normal ocular movements and deep tendon reflexes, slurred speech, head titubation, and global cerebellar ataxia (video 1, links.lww.com/NXG/A403). Cognition was normal. Brain MRI (MRI) showed mild cerebellar atrophy (figure, B and C). Given the dominance inheritance pattern of the disease within the family, the SCA1, 2, 3, 6, 7, and 10 genes were tested for repeat expansions but was negative. WES was performed using a routine procedure including exome capture with Agilent Clinical Research Exome v1, followed by sequencing using the Illumina NextSeq platform. WES identified a novel heterozygous missense variant c.10906T > G, p.Tyr3636Asp in the SCA45 gene, FAT2 (ENST00000261800.5).

\section{Patient 2}

The sister of patient 1, 79 years old, presented with a 6-year history of progressive cerebellar ataxia. She also suffered of mild dysarthria, slurred speech, and dysphagia. Neurologic examination showed global ataxia (video 1). Cognition and ocular movements were normal, as well as deep tendon reflexes. Brain MRI showed mild cerebellar atrophy (figure, D and E). WES identified the same c.10906T>G, p.Tyr3636Asp variant in FAT2.

\author{
Correspondence \\ Dr. Pedroso \\ jlpedroso.neuro@gmail.com
}

\section{MORE ONLINE}

\section{Video}

From the Universidade Federal de São Paulo (T.Y.T.S., A.B.R.R., J.L.P., O.B.); Fleury Medicina Diagnóstica (C.R.Q.), São Paulo, Brazil; and University of Groningen (D.S.V.), Groningen, the Netherlands.

Funding information and disclosures are provided at the end of the article. Full disclosure form information provided by the authors is available with the full text of this article at Neurology.org/NG.

This is an open access article distributed under the terms of the Creative Commons Attribution-NonCommercial-NoDerivatives License 4.0 (CC BY-NC-ND), which permits downloading and sharing the work provided it is properly cited. The work cannot be changed in any way or used commercially without permission from the journal. 


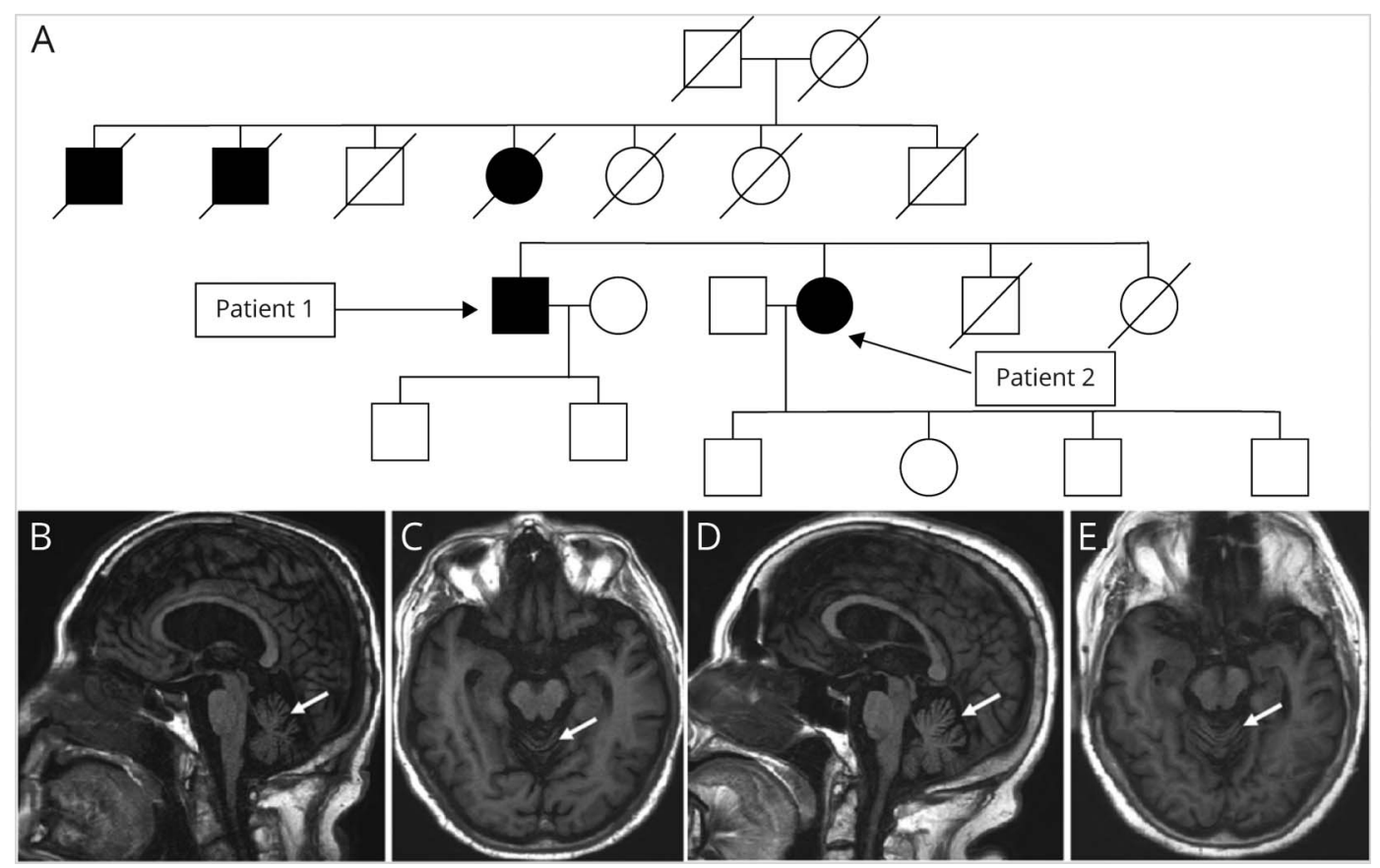

(A) Heredogram discloses many family members affected, suggesting an autosomal dominant inheritance. Sagittal (B) and axial (C) T1-weighted brain MRI of patient 1 with SCA45 shows mild cerebellar atrophy (arrows). Sagittal (D) and axial (E) T1-weighted brain MRI of patient 2 with SCA45 also discloses mild cerebellar atrophy (arrows).

\section{Discussion}

SCA45 (MIM \#617769) related to the FAT2 gene variants is an unusual conventional SCA type. ${ }^{2}$ SCA45 was reported in 2017 in a WES-based study that reported 2 different missense variants c.10758G $>$ C, p.Lys3586Asn and c.10946G >A, p.Arg3649Glu affecting highly conserved amino acids in the last cadherin repeat and linker region between the cadherin repeat and the laminin A-G of FAT2. The first variant was identified in a patient who presented with pure cerebellar ataxia, downbeat nystagmus, dysarthria, a positive family history, and disease onset after the age of 40 years. The second case also had slowly progressive ataxia and a disease onset after the age of 50 years, but no family history. ${ }^{2}$ Moreover, a recent study including patients with CANVAS phenotype and negative for the RFC1 repeat-expansion disclosed one subject with the heterozygous c.4370T $>C$, p.Val1457Ala variant affecting the $13^{\text {th }}$ cadherin domain of FAT2. ${ }^{3}$

The p.Tyr3636Asp variant described in our report is novel and absent in control databases (gnomAD, $\mathrm{ABraOM}$ ) and literature. Although this may seem a variant of unknown significance, there are some relevant points to be considered: (1) the variant is located close to the previously reported p.Lys3586Asn variant in a well-established functional domain, (2) cosegregates with disease, and (3) the phenotype is highly similar to cases described in previous studies of SCA45-we considered this variant likely pathogenic and the cause of the ataxia.
FAT2, previously named MEGF1, belongs to the family of human FAT genes. ${ }^{4}$ AT2 is a large transmembrane adhesion molecule specifically expressed in the cerebellar granule cells, playing an important role in postnatal cerebellum development. ${ }^{5}$ FAT genes are the human homologous of Drosophila fat. ${ }^{6}$ Recently, the depletion of fat in Drosophila was reported to cause neurodegeneration of the fly eye, very likely to deficits in autophagy. ${ }^{7}$ The question remains whether FAT2 in humans is also implicated in autophagy and thereby mediates neuronal homeostasis in the cerebellum needs to be established.

So far, only one family with a few affected members and one sporadic case carrying likely pathogenic FAT2 variants have been described. All cases presented with a slowly progressive late-onset ataxia. ${ }^{2,3}$ Therefore, additional cases with likely pathogenic variants presenting with late-onset ataxia and future functional studies on how variants in FAT2 cause late-onset ataxia will further add to link between FAT2 and SCA45. In conclusion, SCA45 seems characterized by a very late-onset cerebellar ataxia and cases presenting with such features without repeat expansions in the most common SCAs should be screened for variants in FAT2 using WES.

\section{Acknowledgment}

The authors would like to thank FAPESP (Fundação de Amparo à Pesquisa do Estado de São Paulo) for having funded this study. 


\section{Study Funding}

This article was funded by FAPESP (Fundação de Amparo à Pesquisa do Estado de São Paulo), grant number 2019/ 15298-1.

\section{Disclosure}

T.Y. Tonholo Silva, A.B.R. Rosa, D. Verbeek and O. Barsottini report no disclosures. J.L. Pedroso received a grant from FAPESP (Fundação de Amparo à Pesquisa do Estado de São Paulo). This article was funded by FAPESP. Full disclosure form information provided by the authors is available with the full text of this article at Neurology.org/NG.

\section{Publication History}

Received by Neurology: Genetics November 19, 2020. Accepted in final form February 3, 2021.

\section{Appendix Authors}

\begin{tabular}{lll}
\hline Name & Location & Contribution \\
\hline $\begin{array}{l}\text { Thiago Y. } \\
\text { Tonholo } \\
\text { Silva, MD }\end{array}$ & $\begin{array}{l}\text { Universidade Federal } \\
\text { de São Paulo, Brazil }\end{array}$ & $\begin{array}{l}\text { Conception, organization, and } \\
\text { execution and writing of the } \\
\text { first draft }\end{array}$ \\
$\begin{array}{l}\text { Augusto B.R. } \\
\text { Rosa, MD }\end{array}$ & $\begin{array}{l}\text { Universidade Federal } \\
\text { de São Paulo, Brazil }\end{array}$ & $\begin{array}{l}\text { Conception, organization, and } \\
\text { execution and writing of the } \\
\text { first draft }\end{array}$ \\
\end{tabular}

Appendix (continued)

\begin{tabular}{lll}
\hline Name & Location & Contribution \\
\hline $\begin{array}{l}\text { Caio R. } \\
\text { Quaio, MD }\end{array}$ & $\begin{array}{l}\text { Fleury Medicina } \\
\text { Diagnóstica, São Paulo, } \\
\text { Brazil }\end{array}$ & $\begin{array}{l}\text { Conception, organization, and } \\
\text { execution and writing of the } \\
\text { first draft }\end{array}$ \\
\hline $\begin{array}{l}\text { Dineke S. } \\
\text { Verbeek, } \\
\text { PhD }\end{array}$ & $\begin{array}{l}\text { University of } \\
\text { Groningen Groningen, } \\
\text { the Netherlands }\end{array}$ & $\begin{array}{l}\text { Conception, organization, and } \\
\text { execution and writing of the } \\
\text { first draft }\end{array}$ \\
$\begin{array}{l}\text { José Luiz } \\
\text { Pedroso, } \\
\text { MD, PhD }\end{array}$ & $\begin{array}{l}\text { Universidade Federal } \\
\text { de São Paulo, Brazil }\end{array}$ & $\begin{array}{l}\text { Conception, organization, and } \\
\text { execution; review; and critique }\end{array}$ \\
\hline $\begin{array}{l}\text { Orlando } \\
\text { Barsottini, } \\
\text { MD, PhD }\end{array}$ & $\begin{array}{l}\text { Universidade Federal } \\
\text { de São Paulo, Brazil }\end{array}$ & $\begin{array}{l}\text { Conception, organization, and } \\
\text { execution; review; and critique }\end{array}$ \\
\hline
\end{tabular}

\section{References}

1. Klockgether T, Mariotti C, Paulson HL. Spinocerebellar ataxia. Nat Rev Dis Primers 2019;5:24.

2. Nibbeling EAR, Duarri A, Verschuuren-Bemelmans CC, et al. Exome sequencing and network analysis identifies shared mechanisms underlying spinocerebellar ataxia. Brain 2017; 140:2860-2878.

3. Rafehi H, Szmulewicz DJ, Bennett MF, et al. Bioinformatics-based identification of expanded repeats: a non-reference intronic pentamer expansion in RFC1 causes CANVAS. Am J Hum Genet 2019;105:151-165.

4. Nakayama M, Nakajima D, Nagase T, Nomura N, Seki N, Ohara O. Identification of high-molecular-weight proteins with multiple EGF-like motifs by motif-trap screening. Genomics 1998;51:27-34.

5. Katoh M. Function and cancer genomics of FAT family genes (review). Int J Oncol 2012;41:1913-1918.

6. Nakayama M, Nakajima D, Yoshimura R, Endo Y, Ohara O. MEGF1/fat2 proteins containing extraordinarily large extracellular domains are localized to thin parallel fibers of cerebellar granule cells. Mol Cell Neurosci 2002;20:563-578.

7. Baron O, Grieshober D, Dias C, Fanto M. Fat cadherins in mouse models of degenerative ataxias. Sci Rep 2019;9:16155. 


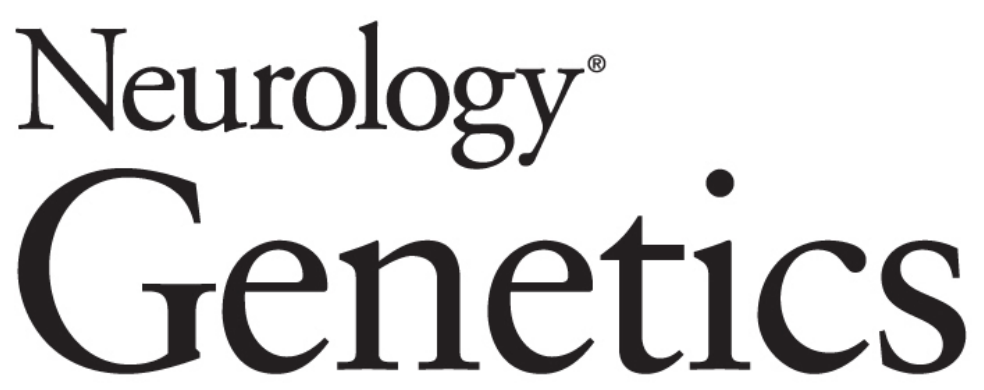

Does SCA45 Cause Very Late-Onset Pure Cerebellar Ataxia?

Thiago Y. Tonholo Silva, Augusto B.R. Rosa, Caio R. Quaio, et al. Neurol Genet 2021;7;

DOI 10.1212/NXG.0000000000000581

This information is current as of March 26, 2021

Neurol Genet is an official journal of the American Academy of Neurology. Published since April 2015, it is an open-access, online-only, continuous publication journal. Copyright Copyright $(2021$ The Author(s). Published by Wolters Kluwer Health, Inc. on behalf of the American Academy of Neurology.. All rights reserved. Online ISSN: 2376-7839.

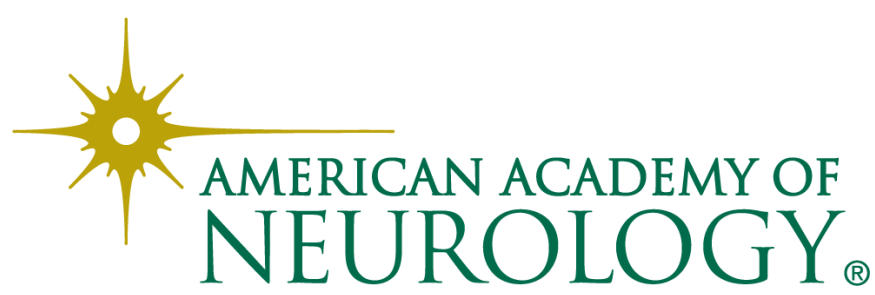




\section{Updated Information \& Services}

References

Subspecialty Collections

Permissions \& Licensing

\section{Reprints}

including high resolution figures, can be found at:

http://ng.neurology.org/content/7/3/e581.full.html

This article cites 7 articles, 0 of which you can access for free at: http://ng.neurology.org/content/7/3/e581.full.html\#\#ref-list-1

This article, along with others on similar topics, appears in the following collection(s):

\section{All Genetics}

http://ng.neurology.org//cgi/collection/all_genetics

\section{All Movement Disorders}

http://ng.neurology.org//cgi/collection/all_movement_disorders

\section{Cerebellum}

http://ng.neurology.org//cgi/collection/cerebellum

Gait disorders/ataxia

http://ng.neurology.org//cgi/collection/gait_disorders_ataxia

Spinocerebellar ataxia

http://ng.neurology.org//cgi/collection/spinocerebellar_ataxia

Information about reproducing this article in parts (figures,tables) or in its entirety can be found online at:

http://ng.neurology.org/misc/about.xhtml\#permissions

Information about ordering reprints can be found online:

http://ng.neurology.org/misc/addir.xhtml\#reprintsus

Neurol Genet is an official journal of the American Academy of Neurology. Published since April 2015, it is an open-access, online-only, continuous publication journal. Copyright Copyright $\odot 2021$ The Author(s). Published by Wolters Kluwer Health, Inc. on behalf of the American Academy of Neurology.. All rights reserved. Online ISSN: 2376-7839.

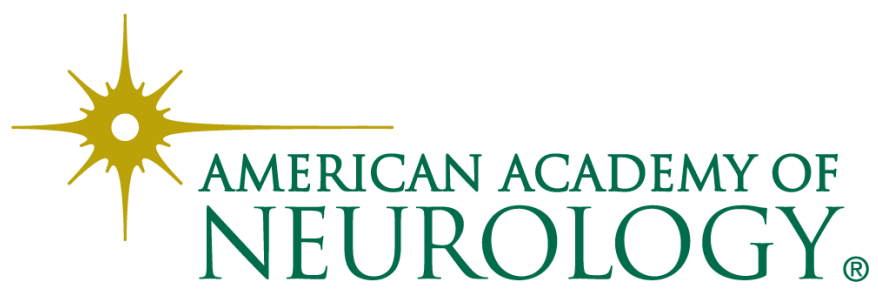

